\title{
Positive and Negative Identity Satisfiers in the Kosovo Conflict
}

\author{
Valery Perry
}

\begin{abstract}
In this article, the author examines the importance of identity as a sustaining factor in the continuing Kosovo conflict. Basic aspects of identity-based conflicts are reviewed, followed by a discussion about positive and negative identity satisfiers: A matrix comparing the identity needs of the Serbs and Albanians in Kosovo is presented, together with the current negative identity satisfiers that are sustaining the conflict, and a set of potential positive identity satisfiers that could help to resolve the conflict in the long-term. This review of the manifestations of unfulfilled identity needs reveals that the disputants share many similar concerns. This commonality is rarely mentioned in the literature on Kosovo, yet could serve as an important starting point for strategies of reconciliation. A regional peacebuilding plan that appreciates the importance of identity issues as conflict sources, possibly modelled after The Pact on Stability in Europeand other multinational stability-building efforts, is proposed, as are a set of potential regional efforts that are necessary if conflict resolution in Kosovo is to succeed.
\end{abstract}

Résumé

Dans cet article l'auteure examine l'importance de l'identité comme facteur cohésifdans le conflit continudu Kosovo. Les aspects fondamentaux des conflits d

\footnotetext{
Valery Perry is a Ph.D. candidate at the Institute for Conflict Analysis and Resolution at George Mason University, Fairfax, VA, USA. Her interest in the Balkans stems in part from experience as an OSCE Election Monitor in Bosnia, and from experience as an intern and researcher at the OSCE Secretariat in Vienna, Austria. Shewill be conducting research in Bosnia from September 1999-September 2000 as a National Security Education Program Fellow.

A modified version of this paper was presented at the University of Massachusetts, Boston, Conference, "Conflict Studies: A New Generation of Ideas," in October 1998.
}

base identitaires sont d'abord passés en reoue. Suit une discussion de la question des satisfecit identitaires positifs et négatifs. Un modele comparant les besoins identitaires des serbes et des albanais $d u$ Kosovo est présenté, en même temps que les satisfecit négatifs actuels qui perpétuent le conflit, et qu'une série de satisfecit positifs potentiels qui pourrait contribuer à résoudre le conflit d long terme. Cette analyse des manifestations de besoins identitaires non assouvis révele que les belligérants ont de nombreuses inquiétudes en commun. Cecaractère commun des problemes est rarement mentionné dans la littérature spécialisée sur le Kosovo, mais pourrait servir de point de départ important dans unestratégie de réconciliation. Est proposé un plan de paix régional qui prendrait la mesure de l'importance des questions identitaires comme source de conflit, possiblement sur le modèle du Pacte de Stabilité en Europe et d'autres efforts multinationaux de stabilisation. On propose aussi un ensemble d'efforts régionaux potentiels, indispensables si on veut que la résolution du conflit au Kosovo soit un succes.

\section{Introduction}

The conflict in Kosovo and the ensuing refugee crisis in Europe have attracted an enormous amount of attention by policymakers, diplomats, and the media throughout 1998 and 1999. A small region, unknown to mostcasual readers just a few months ago, now dominates the news. However, while the quantity of coverage has increased, the analysis has often been simplistic, with the complex conflict being framed primarily in terms of religious or territorial differences. The conflict in Kosovo appears to be about land and history, religion and language, culture and borders. The analysis of this conflict offered here touches on all of these topics through the singular theoretical framework of identity.
This preliminary review of identity issues in Kosovo seeks to dispel the notion that the conflict is simply the result of a struggle for territory or an inevitable flare-up in a long history of ethnic hatreds, by examining the conflict through the lens of identity. Basic aspects of identity-based conflicts will be reviewed to determine their applicability to Kosovo, followed by a discussion about positive and negative identity satisfiers. Identification of the identity issues thatneed to be addressed will enable the development of a set of potential policy goals and peace-building measures that are prerequisites to $a$ successful resolution of the conflict in the Kosovo region.

\section{Identity-Grounded Conflicts}

Theories of identity in conflict and conflict resolution are based in part on the notion that conflict is a result of the nonfulfilment of basic human needs. ${ }^{1} \mathrm{Hu}-$ man needs theorists seek to identify basic human needs that must be met if one is to minimize conflict. The list of potential universal human needs include tangible, physical needs such as food, water, and shelter, as well as less tangible but equally important needs such as security, meaning, or identity. These less-tangible needs can be even more important than basic physical needs, a point Rich Rubenstein highlights while referencing Johan Galtung: "In many cases of ethnic, religious, and national violence, needs for security, welfare, and freedom aresystematically subordinated to the imperatives of identity, recognition, and belongingness." 2

The concept of identity is broad, and encompasses aspects of both individual and group identity. In his discussions on the subject, Galtung notes several aspects of identity that must be recognized, including having a sense of roots or belongingness; being able to understand (or to attempt to understand) social forces; and having the

Refuge, Vol. 18, No. 3 (August 1999) 
chance to seek a sense of purpose or meaning in life. ${ }^{3}$ Thesenon-material yet vital needs are critical to the development and self-actualization of an individual or a collective. Conflicts may arise when the fulfilment of personal or group identity needs is, or is perceived to be, impossible. Fulfilment of identity needs can be extremely difficult as they are dependent on the structures in society, and on the role or position of an individual or group in that society. $A$ society that is structured in such a way as to deny people the opportunity to positively fulfil their identity needs (whether the prohibiting structures are intentional or not), creates a situation in which the deprived group will struggle to fulfil these needs by negative means that could lead to conflict.

The ways in which identity needs (or other basic needs) may be fulfilled are called satisfiers. Needs may be fulfilled through either positive or negative satisfiers, depending on the circumstances in which fulfilment is being sought. Negative satisfiers fulfil an identity need at the expense of the similar needs of another party, while positive satisfiers fulfil identity needs without infringing on the needs of others. Manfred Max-Neef presents a useful framework for understanding identity needs and potential satisfiers in his work on human scale development.Max-Neefbreaks down the idea of identity into four parts:

1) Being (a sense of belonging, self-esteem, and assertiveness);

2) Having (historical memory, symbols, customs, values, traditions);

3) Doing (self-recognition, actualization, commitment); and

4) Interacting (social rhythms). 5

This typology is useful, for.it recognizes aspects of identity that are internal and external, individual and collective. It also recognizes the interoperability and interdependence of these aspects of identity, for fulfilment of one of these four categories is not sufficient to sustain a healthy, complete identity-all must be attainable. This comprehensive view of identity is important, and as will be illustrated, is often overlooked in media coverage of the conflict in Kosovo, which tends to rely heavily on the more readily visible "having" dimensions of the conflict.

An appreciation and understanding of issues of identity in the current Kosovocrisis will be key to any possible resolution of the conflict. Power, leadership, or economic issues could be addressed in a formal agreement, but without successfully addressing the identity needs of the parties, settlement-letalone resolution-willnotbe possible in the long term. The current conflict is rooted in an environment in which all identity needs, on both sides, are being fulfilled by negativesatisfiers. This has been the case for so long, and the negative satisfiers have become so deeply ingrained, that it is difficult to even consider the existence of otheroptions. The challenge, then, is to identify satisfiers that fulfil identity needs of both parties. Such attentive options must beidentified, for if they arenot, the only future for Kosovo will be ethnic segregation-possibly carried out through ethnic cleansing, or continued conflict and oppression.

\section{Identity Needs and Satisfiers in Kosovo}

The following review of identity needs in Kosovo is unique because it seeks to illustrate the similarity and interdependence of the identity needs of both the main parties to the conflict, rather than focusing on their seemingly intractable differences. Seven aspects of identity have been selected from Max-Neef's framework, representing each of the four categories of needs noted above. These aspects have been selected because they play an important role in the current conflict, and because-though this is an extremely difficult task - they can be addressed in time within a comprehensive regional stability plan. Within this matrix of needs, the current negative satisfiers arenoted, and potential positive satisfiers are suggested.

This matrix illustrates the broad nature of identity issues in Kosovo, and while it clearly illustrates the gap between positive and negative satisfiers, it also reveals the close interdependence between the identity needs of both groups. In light of the intensified war of 1999 and the resultant refugee crisis, addressing these identity issues must bea key component of any potentially successful peacemaking effort. The following section will suggest methods of supporting and attaining a regionalenvironment in which positive satisfiers could be adopted by both parties-an admittedly difficult, though necessary task.

\section{The Role of Regional \\ Reconstruction in Identity Transformation}

At first glance, the positive satisfiers offered as options in the above matrix appear to be overly optimistic or idealistic; this perception is due to the fact that the conflict in Kosovo has been framed solely in terms of negative satisfiers and zero-sum options for solong. It would, however, be unreasonable to expect positive satisfiers to replace negative satisfiers in ashort period of time; many of the proposed positive satisfiers could be achieved only as the result of a gradual and dedicated process of confidence building.

As peacemaking efforts continue through the spring and summer of 1999 , there is an increasing realization that peace and stability in Kosovo will only be achieved if peace and stability are secured in the Balkan region as a whole. There have been suggestions from several corners for a regional rebuilding effort based on the use of conferences or roundtables with Balkan and broader European participation, focused on the eventual integration of Kosovo and the rest of the Balkan region into an increasingly integrated Europe. Such an effort could be modelled after the Pact on Stability in Europe, which addressed postCold War stability and security issues in Central and Eastern Europe through a series of regional roundtables. ${ }^{6}$

TheStability Pact (often referred to as the Balladur Plan) sought to increase stability among countries with histories of tenuous border or ethnic relations by promoting an atmosphere of cooperation and "good neighbourliness." A two-fold approach was adopted. First, 
Table 1: Kosovo Identity Needs and Satisfiers Matrix

\begin{tabular}{|c|c|c|c|}
\hline Identity Need & Satisfiers & Serbs & Kosovan Albanians \\
\hline \multirow[t]{2}{*}{$\begin{array}{l}\text { Shared and } \\
\text { proud history } \\
\text { (Having) }\end{array}$} & Negative & $\begin{array}{l}\text {-promulgation of myths and legends that } \\
\text { perpetuate a culture of victimization } \\
\text { equation of Kosovo Albanians with past } \\
\text { enemies or oppressors }\end{array}$ & $\begin{array}{l}\text {-rise of Albanian nationalism, with emphasis on } \\
\text { centuries-long lack of nation-state status } \\
\text { - increasing support for a "Greater Albania" }\end{array}$ \\
\hline & Positive & $\begin{array}{l}\text {-reconciliation efforts to complete the } \\
\text { mourning of past defeats; stopping the } \\
\text { transgenerational transmission of chosen } \\
\text { trauma } \\
\text { - co-development, with Albanians, of a } \\
\text { Kosovan history that acknowledges Serb } \\
\text { lel!:end but is based on obiective fact }\end{array}$ & $\begin{array}{l}\text { - co-development with Serbs, of Kosovan history that } \\
\text { acknowledges a Serbian legacy as well as an } \\
\text { Albanian historical presence, and which is based on } \\
\text { objective fact } \\
\text { - increase of cultural and economic ties with } \\
\text { Albanians in Albania, Macedonia, and other } \\
\text { recions }\end{array}$ \\
\hline \multirow[t]{2}{*}{$\begin{array}{l}\text { Collective group } \\
\text { esteem } \\
\text { (Being) }\end{array}$} & Negative & $\begin{array}{l}\text {-stereotyping of the "other" } \\
\text {-casting present day Kosovan Albanians } \\
\text { as "Turks" bent on Serb oppression }\end{array}$ & $\begin{array}{l}\text { - stereotyping of the "other" } \\
\text { - casting present day Serbs as "chetniks } \\
\text { the creation of Greater Serbia }\end{array}$ \\
\hline & Positive & $\begin{array}{l}\text { - promoting cultural exchange with other } \\
\text { regional groups } \\
\text { - improvement of esteem through the } \\
\text { cultivation of a positive in!'l image (possibly } \\
\text { through a series of regional roundtables) }\end{array}$ & $\begin{array}{l}\text { - promotion of cultural exchange with other regional } \\
\text { groups (especially Macedonians, who share similar } \\
\text { identity issues) } \\
\text { - improvement of esteem through cultivation of a } \\
\text { positive in!'l image (possibly through a series of } \\
\text { recional roundtables) }\end{array}$ \\
\hline \multirow[t]{2}{*}{$\begin{array}{l}\text { Religion } \\
\text { (Having) }\end{array}$} & Negative & $\begin{array}{l}\text {-fear of non-Orthodox religions } \\
\text { - restrictions on displays of non- } \\
\text { Orthodox faith }\end{array}$ & -new manifestations of Islamic con \\
\hline & Positive & $\begin{array}{l}\text {-strengthening and encouragement of } \\
\text { Orthodoxy without belittling non- } \\
\text { Orthodox believers } \\
\text {-cooperation with non-Orthodox } \\
\text { community leaders on superordinate } \\
\text { goals }\end{array}$ & $\begin{array}{l}\text {-encouragement of studies and practice of Islam as it } \\
\text { pertains to the history of the region } \\
\text { - cooperation with non-Muslim community leaders } \\
\text { on superordinate goals }\end{array}$ \\
\hline \multirow[t]{2}{*}{$\begin{array}{l}\text { Language } \\
\text { (Having) }\end{array}$} & Negative & $\begin{array}{l}\text {-promotion of Serbian language by } \\
\text { restricting Albanian language education }\end{array}$ & $\begin{array}{l}\text { - linking of language issues to radical political } \\
\text { forces }\end{array}$ \\
\hline & Positive & $\begin{array}{l}\text { - promotion of Serbian language through } \\
\text { education, promotion of great Serbian } \\
\text { writers and other cultural examples } \\
\text { - promotion of bi-lingualism in ethnically } \\
\text { mixed areas }\end{array}$ & $\begin{array}{l}\text { - cultivation of the use of language in education } \\
\text { and literature } \\
\text { - promotion of bi-lingualism in ethnically mixed } \\
\text { areas }\end{array}$ \\
\hline \multirow[t]{2}{*}{$\begin{array}{l}\text { SeIf- } \\
\text { actualization } \\
\text { (Doing) }\end{array}$} & Negative & $\begin{array}{l}\text { - promotion of Serbian opportunity by } \\
\text { eliminating or prohibiting Albanians } \\
\text { from segments of the workforce }\end{array}$ & $\begin{array}{l}\text { - alliances with militant nationalist groups such } \\
\text { an the KLA in lieu of legitimate representation }\end{array}$ \\
\hline & Positive & $\begin{array}{l}\text { - focus on economic rebuilding to } \\
\text { provide more opportunities for all } \\
\text { residents }\end{array}$ & $\begin{array}{l}\text { - promotion of education in recognized } \\
\text { institutions } \\
\text { - focus on economic rebuilding to provide more } \\
\text { opportunities for all residents }\end{array}$ \\
\hline \multirow[t]{2}{*}{$\begin{array}{l}\text { Recognition } \\
\text { (Doing) }\end{array}$} & Negative & $\begin{array}{l}\text {-denying voice, political office or } \\
\text { expression to non-Serbs }\end{array}$ & $\begin{array}{l}\text {-increased visibility of KLA to attract int'l } \\
\text { attention } \\
\text {-increased ties with Albanian nationalists }\end{array}$ \\
\hline & Positive & $\begin{array}{l}\text {-int'l recognition through collaborative } \\
\text { decision making efforts with non-Serbs } \\
\text {-allow and encourage int'l NGOs to } \\
\text { bring aid to the region to rebuild }\end{array}$ & $\begin{array}{l}\text {-continued willingness to work with int'l } \\
\text { organizations to bring relief to the region } \\
\text {-commitment to peaceful means of resolution }\end{array}$ \\
\hline \multirow[t]{2}{*}{$\begin{array}{l}\text { Social interaction } \\
\text { (Interacting) }\end{array}$} & Negative & $\begin{array}{l}\text {-aggressive actions and attacks by } \\
\text { paramilitary groups }\end{array}$ & $\begin{array}{l}\text { - KLA development as primary Albanian } \\
\text { civic/community organization }\end{array}$ \\
\hline & Positive & $\begin{array}{l}\text {-joint efforts to rebuild deteriorated } \\
\text { infrastructure and economy for all } \\
\text { residents }\end{array}$ & $\begin{array}{l}\text {-joint efforts to rebuild deteriorated infrastructure anc } \\
\text { economy for all residents }\end{array}$ \\
\hline
\end{tabular}


bilateral and trilateral agreements between the targeted states were reaffirmed or developed and formally registered as a part of the Pact. This constituted the more traditional diplomatic aspect of the Pact. Second, a series of concrete and well-defined projects, meant to foster improved relations between countries, were identified. These projects included border infrastructure development (roads, bridges, telecommunications); cultural initiatives (ethnic minority rights support, bilingual language training efforts, and jointly developed history projects); economic developmentefforts; and legal and environmental projects. These cooperative efforts were based on the belief that the pursuit of superordinate goals toward an improved regional future would help to defuse historical animosities, and usher in a new generation geared more toward peaceful coexistence than tense border sharing. The Pact was a truly multinational effort, with support from participating states, the EU, and the OSCE.

A Stability Pact for the Balkans must take identity issues into consideration as a key component of regional stability and security. While not a traditional diplomatic policy goal, this addressal of identity needs can be achieved; for example, as several of the above-noted identity needs could be positively filled through efforts at rebuilding the warravaged Kosovo region. Individuals seeking self-actualization, recognition, and social interaction (especially youth), could begin to find fulfilment in reconstruction efforts in rebuilding bridges, schools, roads, and other community necessities, funded through a regional development plan, rather than through continued destruction. Especially for young unemployed men (of whatever ethnic heritage), who can often gravitate toward militant nationalistic movements to overcome feelings of alienation and disenfranchisement, constructive pursuit of superordinate goals could providea beneficial identity strengthening activity.

These identity needs could also be fulfilled through increased and positive interactions within the greater Euro- pean and broaden international community. Participation in programs geared to secure entry (or re-entry) into international organizations (IOs) such as the OSCE, the Council of Europe, or the EU, could provide national and regional goals similar to the goal of the Central and East European countries to enter NATO or the EU. Participation in these IOs would also take place under more positive circumstances, since construction rather than destruction would be the primary goal. Establishment of a regional organization, comprised of the many states existing on the Balkan peninsula could also serve as an outlet for positive change and recognition.

The "having-focused" identity needs of history, language, and religion will be difficult to address positively, especially in light of the warfare, expulsions, and refugee crises of 1999. Despite the difficulty, they will have to be addressed if Kosovo is to contain a multi-ethnic community. A regionalstability pact would do well to look to past successes to determine the best way to address these cultural issues. For instance, the Pact on Stability in Europe contained several projects geared towards cultural cooperation, including language training (particularly in Estonia and Latvia, with regard to the resident Russian populations); a history commission geared towards reconciliation between Hungary and Romania; and cooperative educational efforts between the Slovak Republic and several other regional countries. Other projects include planned studies on ethnic minorities in Hungary, the Slovak Republic and other Central European states. These efforts can be reviewed to identify their strengths and weaknesses, and then can be selectively applied to the arduous task of building ethnically stable communities in Kosovo.

The OSCE's past and present experience in promoting stable relations can also provide a model for identity-fulfilling effortsinKosovo. The OSCEMission to Latvia has dealt primarily with issues of language, education, and related concerns in a population struggling to come to terms with the sizable regional Russian community in its midst. The OSCE
High Commissioner on National Minorities (HCNM) could play a role in addressing ethnic identity issues in Kosovo, as the HCNM has had experience in addressing similar issues in Hungary, Romania, Kazakhstan, Albania, and other countries. The Office for Democratic Institutions and Human Rights (ODIHR) could help support identity issues in Kosovo through its commitment to the human dimension of regional security, promoting and supporting human rights, civil society, and rule of law over arbitrary, ethnicallybased or biased practices. These efforts could be pursued through the reinstatement of an OSCE Mission to Kosovo (disbanded in June 1993), working undera greater framework for regional stability-building.

Addressal of the last identity issue identified in the matrix, collective group esteem, will in large part stem from the successful attempts at positively fulfilling the other six identity needs noted. $A$ sense of having some control over one's individual or group destiny, and of belonging to an environment in which one's present and future appears to be safe and stable, will hinge on regional developmentefforts. Inlight of the intensity of the conflict in the past year, this might seem impossible to some. But again, without it, Kosovo cannot exist as a stable multi-ethnic region. The regional establishment of trust, confidence, and justice will only be realized through confidence-building measures, cooperative development efforts, and-most difficult-through the fair prosecution of war crimes. If achieved, the positive satisfiers will provide for a fulfilment of identity that could create a foundation for shared power and responsibility in the region. If positive satisfiers are not identified and preserved, the conflict will continue, possibly ending only with the creation of an "ethnically pure" region.

\section{Concluding Remarks}

Galtung has noted that parties in conflict already havea relationship; if there was none, there would be no conflict. It is precisely due to the long-standing relationships and historic interactions 
of groups in Kosovo through the past several centuries that this conflict is so deep-rooted. In the wake of the tragedies of 1999, there are a limited number of unpalatable political solutions:

1) the status quo, with continued Serb domination of Kosovo within Yugoslavia (less likely since NATO's involvement);

2) reinstated autonomy for Kosovo, possibly through the elevation of Kosovo's status within Yugoslavia to that of a republic, so that Serbia, Montenegro, and Kosovo become equal players within the nation (an increasingly unlikely solution as Kosovo Albanian distrust of Belgrade grows); or

3) the establishment of an independent Kosovan state, through partition contingent upon the defeat of Belgrade (a potentially destabilizing regional exercise in redrawing maps)

Regardless of which of these solutions is ultimately implemented, the key issues of identity will remain and must be addressed through a broader program. A Stability Pact for the Balkanssupported by the European and wider international community, dedicated to the attainment of longterm goals, and adhering to a policy of long-term involvement other than short-term superficial achievementswould go a long way toward rebuilding the physical, tangible infrastructure of the region, as well as addressing important issues of identity. However, it will be important to recognize that, while roads and bridges can rebuilt in a matter of months, identity issues take time and commitment, are achieved through gradual confidence building, and are ultimately successful only after a generation becomes accustomed to peaceful coexistence. Unless an ethnically pure Kosovo is established-a scenario only attainable through significant bloodshed and population transferthere will continue to be a conflicting set of identity needs held by both parties that must be addressed. Whether these needs are met through negative or through positive means will be vital to regional security and stability. I I

\section{Notes}

1. For a review of human needs theory, see Conflict: Human Needs Theory, edited by John Burton (New York: St. Martin's Press, 1990).

2. Rich Rubenstein, "Basic Human Needs Theory: Beyond Natural Law," in Conflict: Human Needs Theory, edited by John Burton (New York: St. Martin's Press, 1990), 346.

3. Johan Galtung. "International Development in Human Perspective." Conflict: Human Needs Theory, edited by John Burton (New York: St. Martin's Press, 1990), 309.

4. Ibid., 307.

5. ManfredMax-Neef,AntonioElizalde,and Martin Hopenhayn, Human Scale Development: Conception, Application, and Further ment: Conception, Application, and Further
Reflections (New York: The Apex Press, Reflections
1991), 33.

1991), 33 .
6. For a review of the status of the Stability Pact, see "The Pact on Stability in Europe: Fulfilled, Failed, or Forgotten?" by Valery Perry, Security Dialogue, June 1999.

\section{Bibliography}

Brass, Paul R. 1991. Ethnicity and Nationalism: Theory and Comparison. London: Sage Publications.

Burton, John W.1988. "Conflict Resolution as a Function of Human Needs." In The Power of Human Needs in World Society, edited by
Roger A. Coate and Jerel A. Rosati, 187204. Boulder, CO: L. Rienner.

Clark, Mary E.1990. "Meaningful Social Bonding as a Universal Human Need." In Conflict: Human Needs Theory, edited by John Burton, 34-59. New York: St. Martin's Press.

Elsie, Robert. 1997. Kosovo: In the Heart of the Powder Keg. New York: Columbia University Press.

Emmert, Thomas A. 1990. Serbian Golgotha: Kosovo, 1389. New York: Columbia University Press.

Gallagher, Tom. 1997. "MyNeighbor,MyEnemy: The Manipulation ofEthnic Identity and the Origins and Conduct of War in Yugoslavia." In War and Ethnicity: Global Connections and Local Violence. New York:

University of Rochester Press. 47-76.

Galtung, Johan. 1990. "International Development in Human Perspective." In Conflict: Human Needs Theory, edited by John Burton, 301-35. New York: St. Martin's Press.

Hook, Sidney. 1943. The Hero in History. New York: The Humanities Press.

Horowitz, Donald L. 1985. Ethnic Groups in Conflict. Berkeley: University of California Press.

Judah, Tim. 1997. The Serbs. Princeton, NJ : Yale University Press.

Max-Neef, Manfred, Antonio Elizalde, and Martin Hopenhayn. 1991. Human Scale Development: Conception, Application, and Further Reflections. New York: The Apex Press.

Rubenstein, Rich. 1990. "Basic Human Needs Theory: Beyond Natural Law."In Conflict: Human Needs Theory, edited by John Burton, 336-55. New York: St. Martin's Press.

Volkan, Vamik. 1997. Bloodlines: From Ethnic Pride to Ethnic Terrorism. New York: Farrar, Straus, and Giroux.

Wilmer, Franke. 1997. "Identity, Culture, and Historicity: the Social Construction of Ethnicityin the Balkans." World Affairs 160, no. 1. c

Centre for Refugee Studies ON-Line WebSite: http://www.yorku.ca/research/crs Email: refuge@yorku.ca 